\title{
STREDOVEKÝ A VČASNONOVOVEKÝ (KOSTOLNÝ) CINTORÍN V NESVADOCH, V POLOHE JÁNOSKA PART (VÝSKUM BÉLU SZŐKEHO V ROKOCH 1938 A 1943)
}

\author{
GABRIEL NEVIZÁNSKY - PÉTER PROHÁSZKA
}

\begin{abstract}
Abstrakt: Stredoveký a včasnonovoveký cintorín v Nesvadoch, v polohe Jánoska part (výskum Bélu Szökeho $v$ rokoch 1938 a 1943). Śtúdia prináša krátku informatívnu správu o cintoríne v Nesvadoch-Jánoska part. Kostolný cintorín sa nachádza na pravom brehu rieky Nitra. Polohu náleziska nazvali podl'a sochy svätého Jána Nepomuckého, ktorá tam v súčasnosti stojí. Na uvedenom mieste odkryl Béla Szöke v rokoch 1938 a 1943 okolo 300 stredovekých a včasnonovovekých hrobov. Na cintoríne sa pochovávalo od 11. do 18. storočia.
\end{abstract}

Kl'účové slová: Slovensko - kostolný cintorín - hroby - hrobové nálezy - archívna archeológia.

The churchyard in Nesvady-Jánoska part from the Middle Ages and the early modern age (excavations conducted by Béla Szöke in 1938 and 1943)

Abstract: This article gives a short introduction to the churchyard in Nesvady-Jánoska part. The churchyard is situated on the bank of the river Nitra, and is named after a statue of St. John of Nepomuk. Béla Szöke excavated on the site ca. 300 graves from the Middle Ages and the early modern age in 1938 and 1943. The churchyard was used from the 11th century until the 18th century.

Key words: Slovakia - churchyard - burials - grave goods - archival archaeology.

\section{Úvod}

Výskum archeologických pamiatok v Nesvadoch je spojený s menom B. Szőkeho, ktorý počas svojho pôsobenia $\mathrm{v}$ Nových Zámkoch viackrát navštívil obec a skúmal tam lokality (Krammer 1962, 5). Zatial' čo staromad’arské nálezy a hroby z rokov 1933 a 1936 nájdené v polohe Partok autor zverejnil (Szőke 1941; Fehér-Éry-Kralovánszky 1962, 57, Nr. 733-738), o výskume v polohe Jánoska part informoval iba v regionálnych novinách (Szőke 1938). Z údajov, ktoré poskytol, boli známe iba lakonické informácie. „V polohe Jánoska part v intraviláne obce vidno ruiny základov kostola z Arpádovskej doby (obr. 1). Okolo nich sa nachádza cintorín s viacerými vrstvami hrobov. V roku 1943 sme z neho preskúmali iba čast', dokopy 275 hrobov. Na základe hrobových nálezov sa na cintoríne pochovávalo od počiatku 11. po koniec 18. storočia Múzeum Nové Zámky - údaj B. Szökeho“ (Fehér-Éry-Kralovánsky 1962, 57). Následné odborné spracovanie a vyhodnotenie uvedeného výskumu bolo doteraz podmienené neobyčajnými komplikáciami. Zatial' čo archeologický materiál je uložený vo fonde Slovenského národného múzea v Bratislave, príslušná súdobá písomná dokumentácia výskumu sa nachádza v Múzeu Flórisa Rómera v Győri.

V rámci projektu SASPRO, financovaného Slovenskou republikou a Európskou úniou, sa nám podarilo identifikovat' a nájst' výskumnú dokumentáciu Bélu Szőkeho, na základe ktorej možno realizovat' všestranné odborné vyhodnotenie sledovaného výskumu.

Spoluzakladatel' a neskorší riaditel' novozámockého múzea Béla Szőke sa narodil v roku 1913 v Malackách, odkial' sa neskôr prest’ahoval s rodičmi do Nových Zámkov. Po ukončení gymnázia začal študovat' právo v Brne a neskôr históriu v Bratislave. Tu sa dostal do úzkeho kontaktu s profesorom Jánom Eisnerom a stal sa jeho asistentom v archeologickom seminári (Krammer 1962, 5-6; Točík 1983, 7). Študoval archeológiu aj na budapeštianskej univerzite, kde sa stal žiakom Ferenca Tompu. Tam si osvojil rad nových poznatkov pre dokumentáciu archeologického materiálu, medzi inými aj používanie predtlačených evidenčných listov pre hrobové celky. V rokoch 1940 až 1945 bol profesorom slovenského gymnázia v Šuranoch. Popritom si však našiel čas aj na zvel'ad’ovanie novozámockého múzea, resp. na terénne archeologické výskumy (Točík 1983, 7-8). Bohaté zbierky múzea sa však stali obetou amerického bombardovania. 


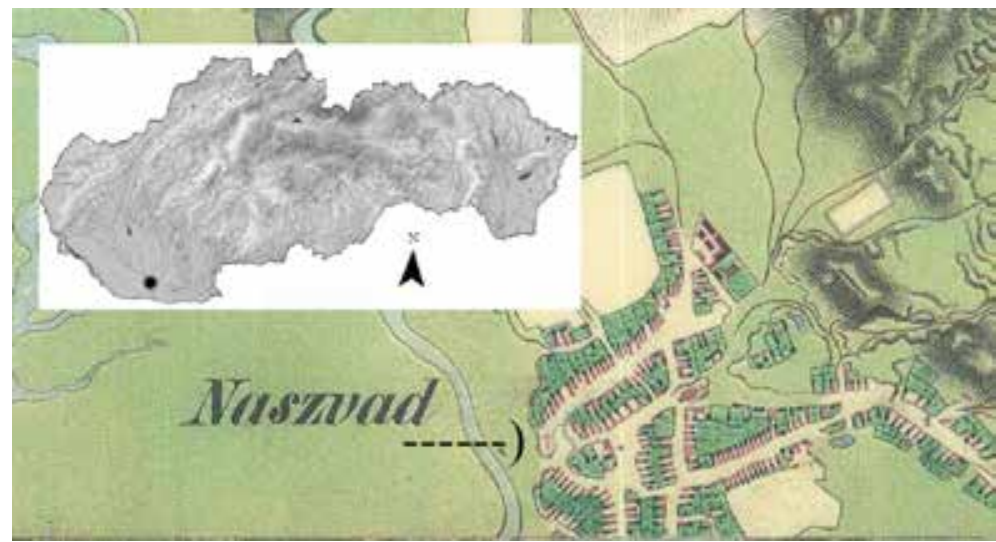

Obr. 1. Nesvady na mapovom liste druhého vojenského mapovania. Zdroj Hadtörténeti Múzeum, Térképtár, Budapest.

Abb. 1. Nesvady auf einer Karte der zweiten militärischen Kartierung. Quelle Militärhistorisches Museum, Kartensammlung, Budapest.

B. Szőkemu sa podarilo niektoré predmety zachránit', medzi inými aj sledovaný nálezový fond z Nesvád, ktorý si po vojne zobral so sebou do Mad’arska. Uvedené nálezy boli spočiatku deponované v Mad’arskom národnom múzeu. Neskôr však, po vymenovaní B. Szőkeho za riaditel’a múzea v Győri ich previezol na nové pracovisko, kde sa stali súčastou archeologickej zbierky. O osudoch antropologického materiálu žial' nemáme informácie. Nachádzajú sa na neznámom mieste, resp. boli zničené počas leteckých náletov, ktoré zasiahli aj budovu múzea. Odborné vyhodnotenie zachránených nálezov znemožnila predčasná smrt’ autora výskumu v roku 1961 (Točík 1983, 8). V šest’desiatych rokoch minulého storočia v rámci rokovaní o výmene kultúrneho dedičstva medzi Československom a Mad’arskom popri početných archeologických a umeleckých artefaktoch sa na Slovensko dostali aj nálezy z Nesvád. Odborná dokumentácia výskumu však zostala v Győri, jej obsahom boli nálezové listy s predtlačenou kresbou kostry v počte $275 \mathrm{ks}$, samostatné plány hrobov, celkový plán pohrebiska, resp. popisné kartóny s popismi a ilustráciami najvýznamnejších a najdôležitejších predmetov. Žial', výskumná dokumentácia sa zachovala iba z roku 1943. O výskume v roku 1938 máme k dispozícii iba niekol'ko záznamov a novinových článkov.

\section{Výskumy Bélu Szőkeho v Nesvadoch, poloha Jánoska part}

Podl’a dokumentov, ktoré sú nám k dispozícii, Béla Szőke realizoval výskumy v Nesvadoch v júli 1938 a v letných mesiacoch roku 1943. O nálezisku v článku uverejnenom v novinách Érsekújvár és vidéke píše nasledovné: „V obci Nesvady na západnom okraji od brehu rieky Nitra malé nerovné námestícko prerušuje dlhé do radov usporiadané domy. V strede námestia na menšej vyvýšenine stoji socha sv. Jána Nepomuckého. Starši obyvatelia spomínajú, že na tomto kopci bol niekedy cintorín, ba aj kostol sa tam nachádzal, ktorého zvon pred Turkami ukryli v studni." Podl'a záznamu v kanonickej vizitácii sochu Jána Nepomuckého, patróna riek, rybárov a lodiarov, ktorého svätorečili v roku 1729, postavili na mieste niekdajšieho kostola niekedy začiatkom 19. storočia (Hegedüs-Tóth 2000, Arcibiskupský archív Esztergom LIB 496 [1846], 4). „(..) inra pagum in loco prioris Ecclesiae ad rippam flumini Nitra existit Statua s. Joanis Nepum (...)“ B. Szőke základy kostola na sledovanom mieste nenašiel. V texte d’alej uvádza, že je to dôsledok dôslednej exploatácie sutín stavby (Szőke 1938). Hoci počas výskumu v roku 1938 neboli nájdené základy kostola, zistili sa hroby prikostolného cintorína. Pre takéto 


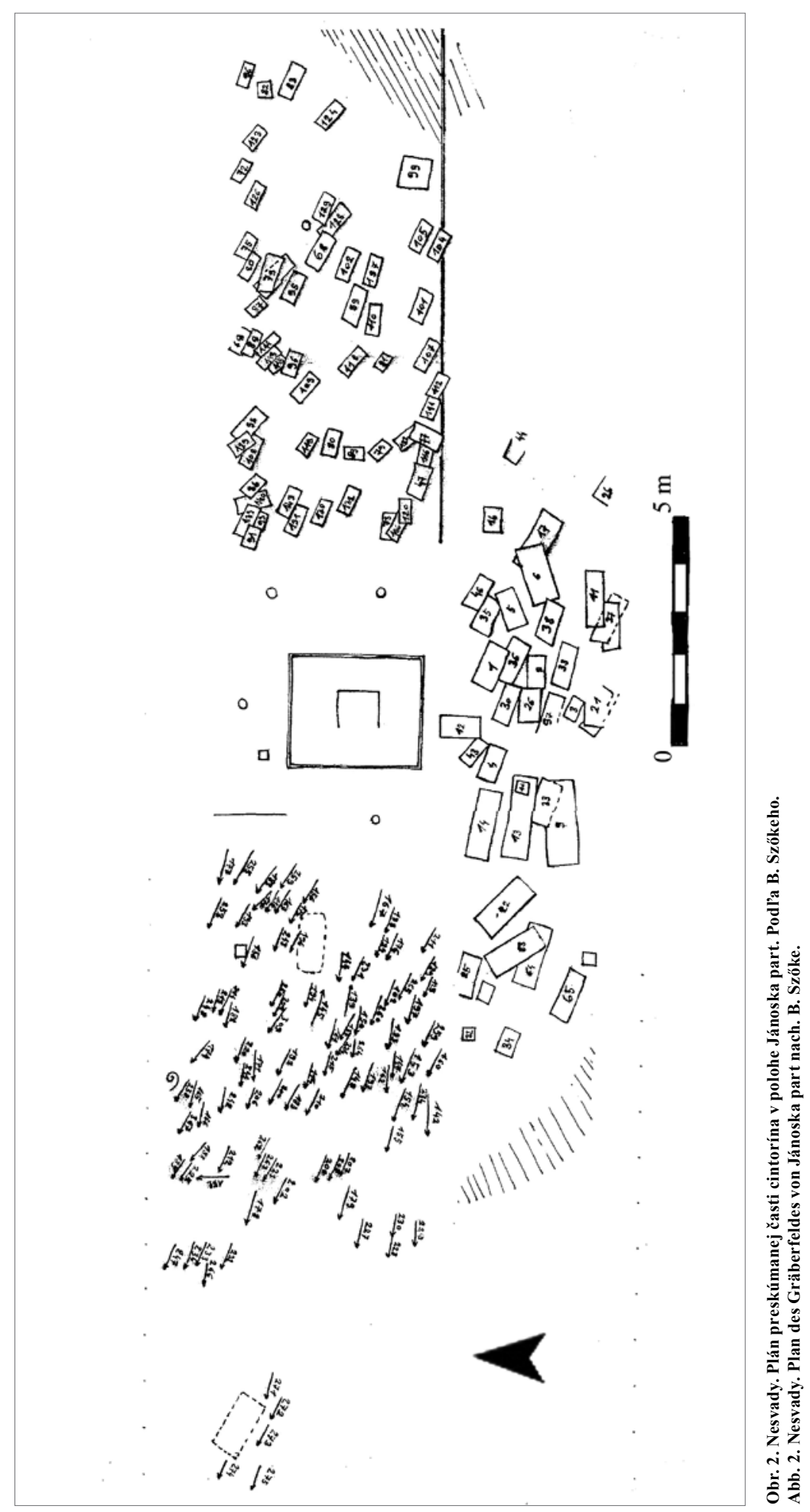


cintoríny - ako uvádza - je príznačné vel'ké množstvo krížom-krážom nad sebou uložených hrobov. Naši skromní predkovia totiž túžili hl'adat' večný odpočinok na malej posvätenej ploche okolo kostola. Preto nové hroby zakladali aj nad starými, ktoré často narúšali. Na odkrytej ploche cintorína sme preto zaznamenali nad sebou pät' až šest' vrstiev nahusto uložených kostier. Najspodnejšie hroby, ktoré pozostávali zo šperkov, patrili do obdobia vlády Arpádovcov. V sledovanej vrstve sa našli strieborné a bronzové esovité záušnice, kvalitný strieborný prsteň upletený z troch jemných drôtov, sedem ametystových korálikov atd'. (Szőke 1938). Na základe nájdených hrobových príloh B. Szőke kladie začiatok pochovávania na cintoríne v Nesvadoch do druhej polovice 11. storočia. Najmladšie hroby na lokalite datujú hrobové prílohy do 19. storočia. To znamená, že pri kostole v Nesvadoch sa pochovávalo až 800 rokov (Szőke 1938).

B. Szőke počas výskumu v Nesvadoch preskúmal plochu s rozlohou približne $350 \mathrm{~m}^{2}$. Celý cintorín však neodkryl, nad’alej zostali časti, ktoré boli neskôr čiastočne devastované. V priebehu záchranného výskumu v roku 1943 prebádal dokopy 275 hrobov (obr. 2). K tomuto číslu musíme ešte prirátat' neznámy počet hrobov, ktoré sa preskúmali v roku 1938. Celkový počet zachránených hrobov na sledovanej lokalite možno odhadnút' na 300. Autor výskumu predpokladal, že v Nesvadoch preskúmal zhruba štvrtinu plochy cintorína. Presnú polohu kostola, resp. jeho pôdorys, však nezistil.

Na preskúmanej časti náleziska obsahovala prílohy sotva tretina dokumentovaných hrobov - 91 (33,1\%). Z toho do 11.-13. storočia možno bezpečne datovat' 43 (47,25\%) hrobov. Zvyšných 48 (52,75\%) hrobov s prílohami patrí do novoveku, konkrétnejšie do 16 . až 18. storočia. Počet hrobov bez príloh je pomerne vysoký - 184 (66,9\%). Značná čast' hrobov, najmä z najstaršieho obdobia, bola neskoršími pochovávaniami devastovaná, o čom svedčia aj nálezy šperkov zo sekundárnych polôh.

\section{Stredoveké hroby a nálezy na cintoríne v polohe Jánoska part}

Miestna l’udová tradícia lokalizuje na hore uvedené miesto starý kostol s patrocíniom sv. Mórica, ktorý bol v priebehu 18. storočia zbúraný. O tomto kostole je zmienka aj v historických prameňoch: „Johannes sacerdos sancti Maurittii de Vaskan-Naswoti“. Podl'a súpisu pápežských desiatkov v roku 1333 farár kostola s patrocíniom sv. Mórica mal príjem 4 hrivny (Györffy 1987, 443). Sledovaný kostol figuruje aj na príslušnom liste druhého vojenského mapovania (obr. 1). Dnešný rímsko-katolícky kostol, zasvätený sv. Jozefovi sa nachádza približne $410 \mathrm{~m}$ na východ a bol postavený v roku 1781 (Dobosi 1997, 79; 2002, 246).

$\mathrm{O}$ hroboch a nálezoch $\mathrm{z}$ Arpádovskej doby máme v dôsledku neúplnosti dokumentácie a svojráznej nálezovej situácie na viacvrstvovom cintoríne k dispozícii iba skromné informácie. Údaje o tvare a rozmeroch hrobových jám úplne absentujú. B. Szőke zaznamenal iba híbky hrobových jám a orientáciu kostier, ktoré okrem nepatrných výnimiek uložili v smere západ východ. Na pláne pohrebiska však evidujeme drobné odchýlky kostier od základnej osi. Z obdobia včasného stredoveku evidujeme iba 12 (27,90\%) neporušených hrobov, u ostatných sme zaznamenali menší-väčší stupeň sekundárnej devastácie. Medzi hrobovými nálezmi takmer bez výnimky dominovali šperky, predmety súvisiace s pohanskými praktikami neboli vôbec zaznamenané. Do kategórie najrozšírenejšieho a najpočetnejšie zastúpeného šperku patria strieborné a bronzové esovité záušnice, ktoré sa našli v 27 hroboch v počte jeden až pät' kusov. To znamená, že až $62,79 \%$ hrobov z obdobia vlády Arpádovcov vybavili týmto všel'udovým šperkom. V 24 prípadoch bol sledovaný typ ozdoby jediným druhom hrobovej výbavy. Na pohrebisku v Nesvadoch používali niekol'ko podtypov - variantov esovitých záušníc. V štyroch prípadoch (hroby 220, 225, 260 a 274) sa našli exempláre s plastickým pozdížnym rebrovaním slučky (obr. 3:2). V hrobe 103 boli prítomné záušnice vyhotovené z tordovaného drôtu (obr. 3:5). Z rozrušených hrobov pochádza vel'ká masívna esovitá záušnica s priemerom $47-49 \mathrm{~mm}$, ktorá sa vyskytuje v hrobových celkoch datovaných do 12.-13. storočia (obr. 3:3). Výskyt a používanie rôznych typov esovitých záušníc je na radových a kostolných pohrebiskách evidovaný permanentne od druhej polovice 10. storočia až do polovice 13. storočia (Bóna 1978, 136-137). 


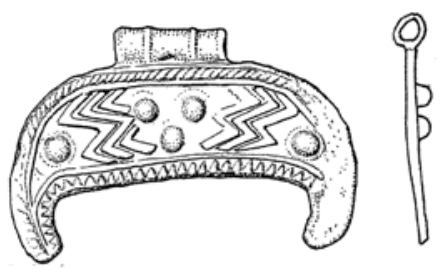

1
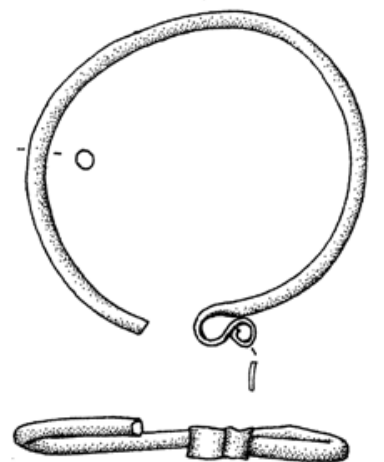

3
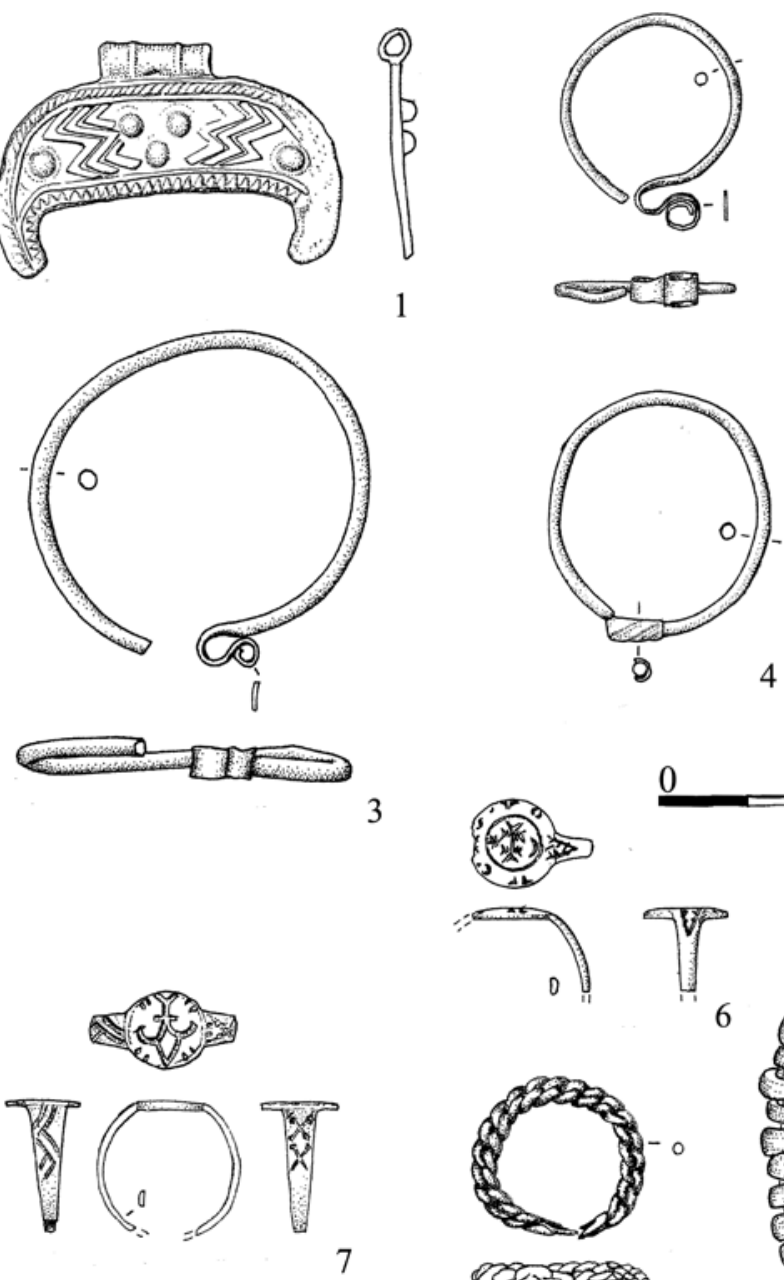

7

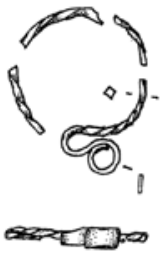

4

0
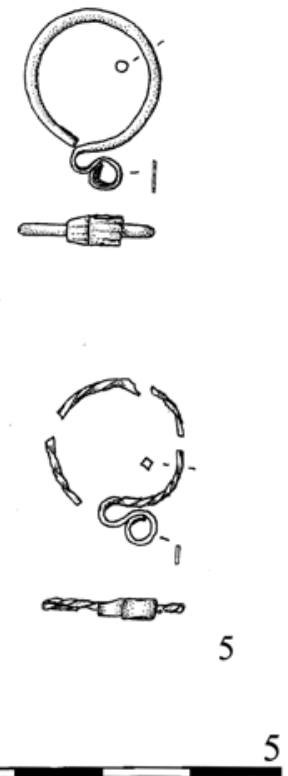

2

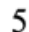

5
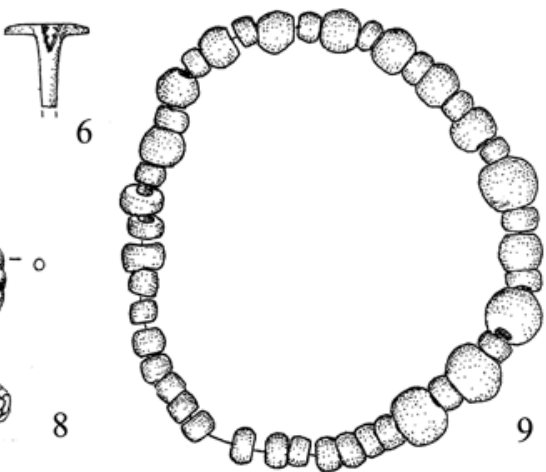

Obr. 3. Nesvady, poloha Jánoska part. Stredoveké nálezy. Kresba Z. Nagyová.

Abb. 3. Nesvady, Lage Jánoska part. Mittelalterliche Funde. Zeichnung Z. Nagyová.

Hrob 196 obsahoval dve bronzové otvorené vlasové krúžky, na jednom konci s natiahnutou, zárezmi zdobenou trubičkou (obr. 3:4). Obdobné šperky sa vyskytujú vo väčšom počte v pokladoch, ktoré ukryli v 13. storočí, najmä počas tatárskeho vpádu (Kulcsár 1996, 249). Jednoduché strieborné alebo bronzové drôtené vlasové krúžky s priemerom v rozmedzí $15-20 \mathrm{~mm}$ boli prítomné v ôsmich-deviatich hroboch. Koráliky z náhrdelníka sa zaznamenali v dvoch hroboch. Kým v hrobe 227 sa našlo 16 bledomodrých sklených artefaktov, pri kostre č. 263 bolo dokopy 26 kusov z horského krištál'u, ametystu, resp. sklenej pasty (obr. 4:1). Súčast’ou náhrdelníka bol aj liaty bronzový závesok polmesiacového tvaru, ktorý sa našiel v sekundárnej polohe (obr. 3:1). Analogický predmet odkryli aj v Malých Kosihách v hrobe 147 spolu s denárom Béla 
dux (1046-1060; Hanuliak 1994, 124, tab. 34:A4b). Honosné lunice z drahých kovov pôvodne vyrábali v umeleckých dielňach v južných provinciách Kyjevskej Rusi a následne ich imitovali v masovom meradle v strednej Európe, resp. v Karpatskej kotline, kde sa našli aj kadluby na ich odlievanie. Jeden z nich objavili v Deutsch Altenburg (Hampel 1907, 266-267), druhý bez udania miesta v Mad’arsku, na území župy Jász-Nagykun-Szolnok (Madaras 2001, 177, obr. 18:1).

Náramky, ktoré sú charakteristické v nálezových celkoch včasného Arpádovského obdobia, sa našli v troch hroboch. Z hrobu 124 pochádzajú fragmenty sledovaného šperku, ktoré vyhotovili $\mathrm{z}$ tordovaného drôtu. $\mathrm{V}$ hrobe 227 sa našiel bronzový tyčinkový náramok štvoruholníkového prierezu, ktorý má povrch zdobený motívom vlčích zubov. Do detailov príbuzný analogický predmet sa našiel v Sedmohradsku, v hrobe 31 na pohrebisku Moldoveneşti (predtým Váralja), v sprievode denára Ondreja I. (1046-1060; Gáll 2013, 527). Ďalší typ liateho bronzového náramku s telom zdobeným hustými ryhami a na koncoch schematicky zobrazenými hadími hlavičkami pochádza z hrobu 263 (obr. 4:3). Ide o pomerne rozšírený šperk, ktorý sa objavuje na pohrebiskách pospolitého l'udu do konca 11. storočia (Kovács 1994, 132-138).

Prstene neboli vo včasnostredovekých hroboch časté. Otvorený pásikový prsteň z hrobu 120 a obdobný artefakt so skleným očkom z hrobu 263 možno rámcove datovat' do 11.-12. storočia (obr. 4:2). Do druhej polovice 13. storočia patrí strieborný, lomenými ryhami zdobený prsteň, na štíte s motívom štylizovanej býčej hlavičky (obr. 3:7), ktorý sa našiel v hrobe 98 (Hlatky 1938, 44-45). Do 13.-14. storočia datujeme tiež zo zberu pochádzajúci prsteň, ktorý má na okraji štítu pseudonápis a v strede dvojkríž, hviezdicu a polmesiac (obr. 3:6; Hlatky 1938, 39-40). Pečatný prsteň spolu s jednoduchou ihlicou z hrobu 25 patria medzi oblúbené šperky Anjouovskej doby (Hlatky 1938, 59).

V Nesvadoch boli vo väčšom počte prítomné aj mince. $Z$ hrobu 69 pochádza uhorská napodobenina friesachského denára z čias vlády Ondreja II. (1205-1235). V hrobe 197 sa našiel anonymný denár typu Huszár 99. Ďalšie dve mince z Arpádovskej doby boli natol’ko skorodované, že sa už určit' nedali.

Na základe hrobových nálezov z obdobia stredoveku možno konštatovat', že v Nesvadoch na cintoríne okolo kostola, ktorého základy sa doposial' síce nenašli, sa začalo pochovávat' v priebehu 11. storočia. V neskorších storočiach v dôsledku nepriaznivých historických udalostí (tatársky vpád) síce došlo na istý čas k prerušeniu kontinuity pochovávania, ale po konsolidácii hospodárskych a politických pomerov sa cintorín začal znova používat'. Analogickú situáciu pozorujeme aj na iných súdobých cintorínoch, napríklad Ducové (Ruttkay 1996), Krásno (Krupica 1978), Nitra - Drážovce (Ruttkay 2005), Nitra - Martinský vrch (Chropovský 1972) atd’., kde sa tiež pochovávalo aj vo včasnom novoveku.

\section{Včasnonovoveké hroby a nálezy na cintoríne v polohe Jánoska part}

Na cintoríne sa pochovávalo aj po porážke pri Moháči, resp. v čase tureckej expanzie, hoci obec po vybudovaní pevnosti $\mathrm{v}$ Nových Zámkoch bola často vystavená tureckým nájazdom. Čast' hrobov patrí do 16.-18. storočia, iba 48 (52,75\%) obsahuje pre toto obdobie charakteristické predmety. Prevažná orientácia hrobov bola zaznamenaná v smere západ - východ. Severo - južná orientácia sa objavila iba výnimočne (Bárdos 1987; Králiková 2007, 159-165). Béla Szőke odkryl v mnohých prípadoch aj zvyšky truhly, ktorej používanie nepriamo dokumentujú i nálezy železných klincov. Čo sa týka polohy horných končatín, evidujeme viac variantov. Najbežnejšou polohou je však uloženie vedla tela, resp. prekríženie predlaktí na bruchu mŕtveho (Králiková 2007, 160-161; Mérei 2010, 48-49). Hrobová keramika, ktorá sa výnimočne objavuje na iných súdobých lokalitách, v Nesvadoch chýba (Králiková 2007, 111-112). Zo zberu pochádza iba niekol'ko črepov.

Neobvyklá poloha kostry sa zaznamenala v hrobe 142. Pohodená kostra na bruchu so skrčenými rukami v lakti ukrývala pod hrudnými kost’ami v koženom vrecúšku kolekciu niekol'ko desiatok západoeurópskych mincí. Poloha mítveho a jeho pochovanie na okraji cintorína signalizuje, že v tomto prípade ide zrejme o hrob cudzinca, ktorý pravdepodobne umrel v dôsledku 

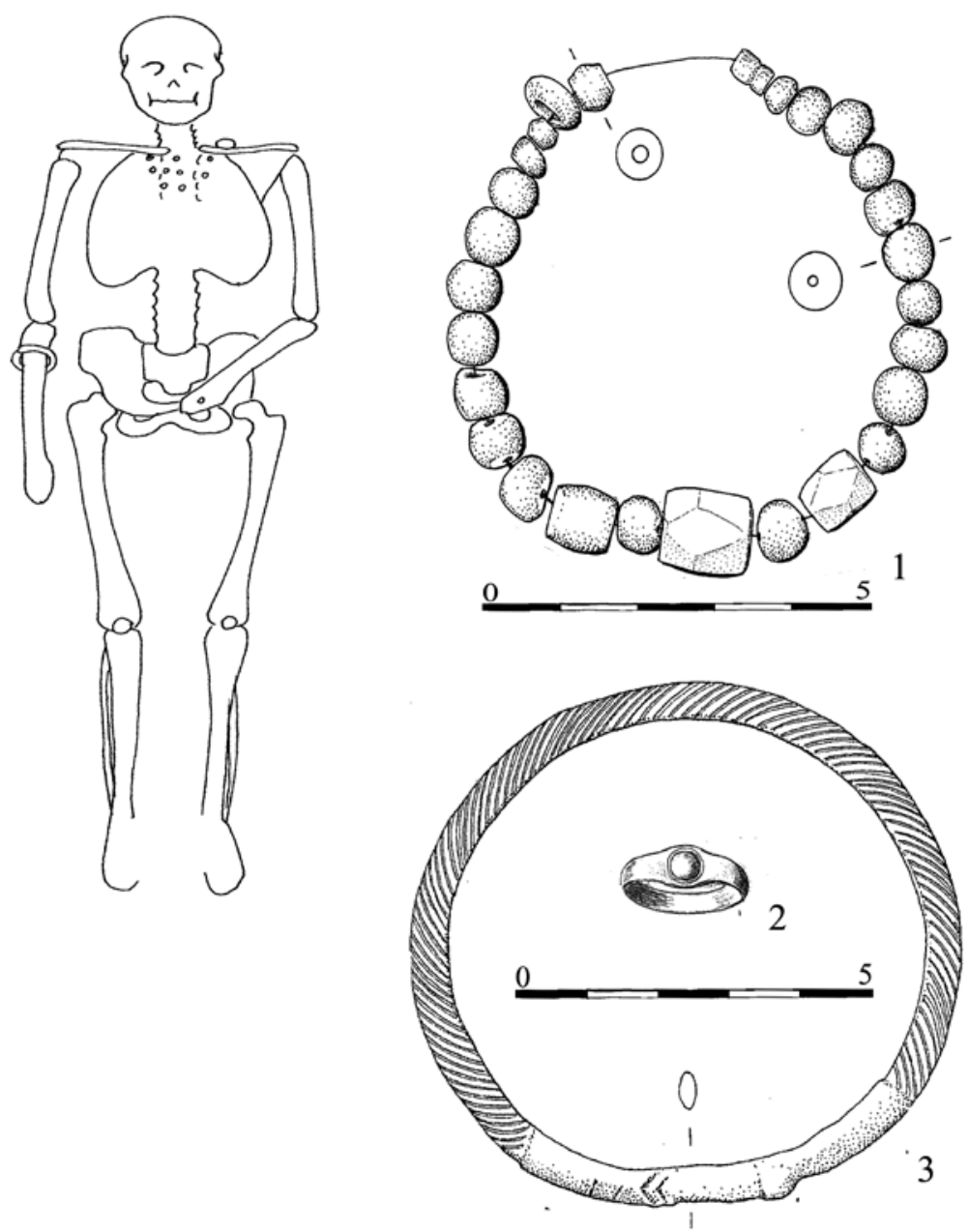

Obr. 4. Nesvady, poloha Jánoska part. Predmety z hrobu 263. Kresba Z. Nagyová.

Abb. 4. Nesvady, Lage Jánoska part. Grab 263 und seine Beigaben. Zeichnung Z. Nagyová.

nejakej epidémie. Podobné pochovávania sú v Karpatskej kotline relatívne zriedkavé, napríklad hrob s vrecúškom drobných mincí v Gortve-Bizove (Drenko 1994, 134-135).

Včasnonovoveké hrobové prílohy sú v porovnaní so stredovekými nálezmi rôznorodejšie a rozmanitejšie (obr. 5:1-9). Jednu čast' z nich tvorili súčasti odevu, resp. kroja. Ďalšia kategória predmetov v hrobovej výbave bola spätá s náboženskou vierou pochovaných (Králiková 2007). Železné podkovičky (obr. 5:2) na podbíjanie opätkov čižiem (Králiková 2007, 66-67; Mérei 2010, 77-78), boli podobne ako rôzne typy spínadiel (obr. 5:3) bežným inventárom včasnonovovekých hrobov mužov aj žien (Kiss-Kiss 1992; 1992a; Králiková 2007, 60-62). Charakteristickým ženským šperkom v Nesvadoch boli rôzne typy vlasových ihlíc s honosne zdobenou hlavičkou, a to v hroboch 17, 21 a 173 (obr. 5:1; 6:1,3-4; Mérei 2010, 58-65). Rovnako často boli zastúpené kratšie jednoduché ihlice s drobnou, gul'ovitou hlavičkou, napríklad v hroboch 17, 25 a 181 (obr. 6:2). V sledovanom období boli charakteristickou súčastou dobového kroja slobodných dievčat rôzne 


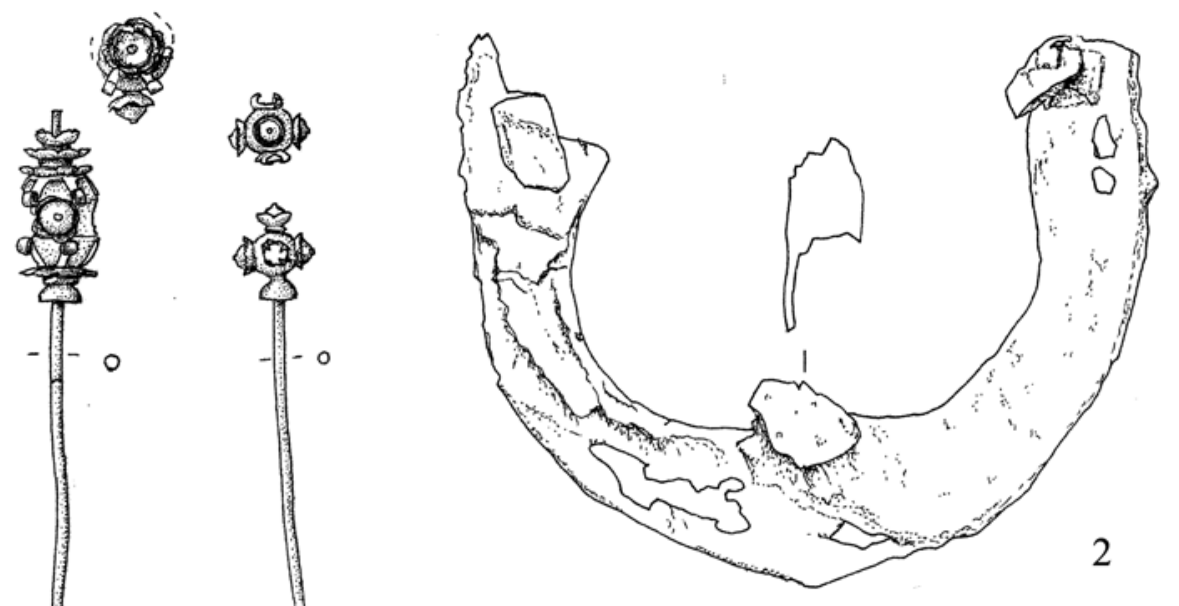

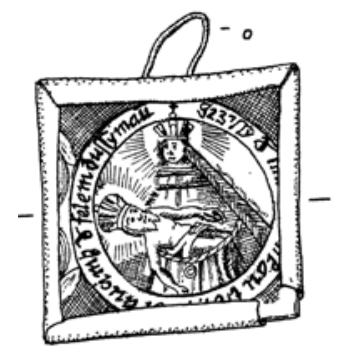

4
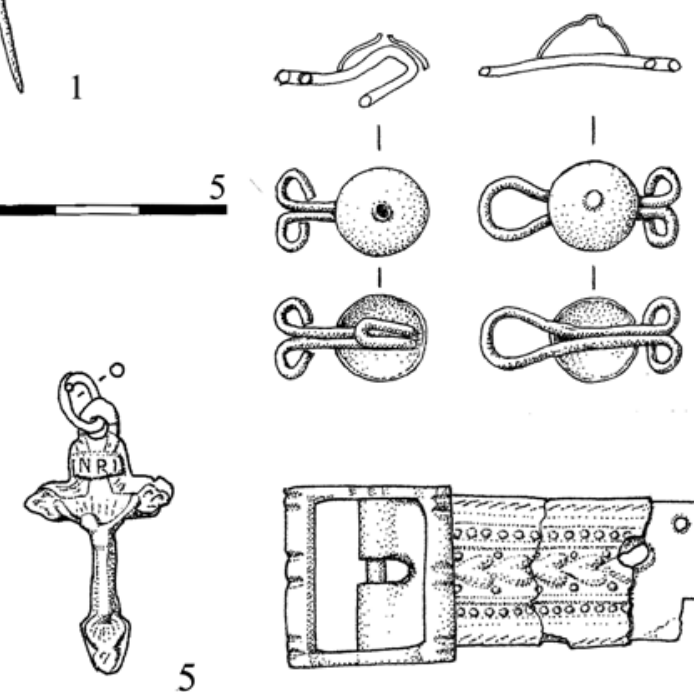

5
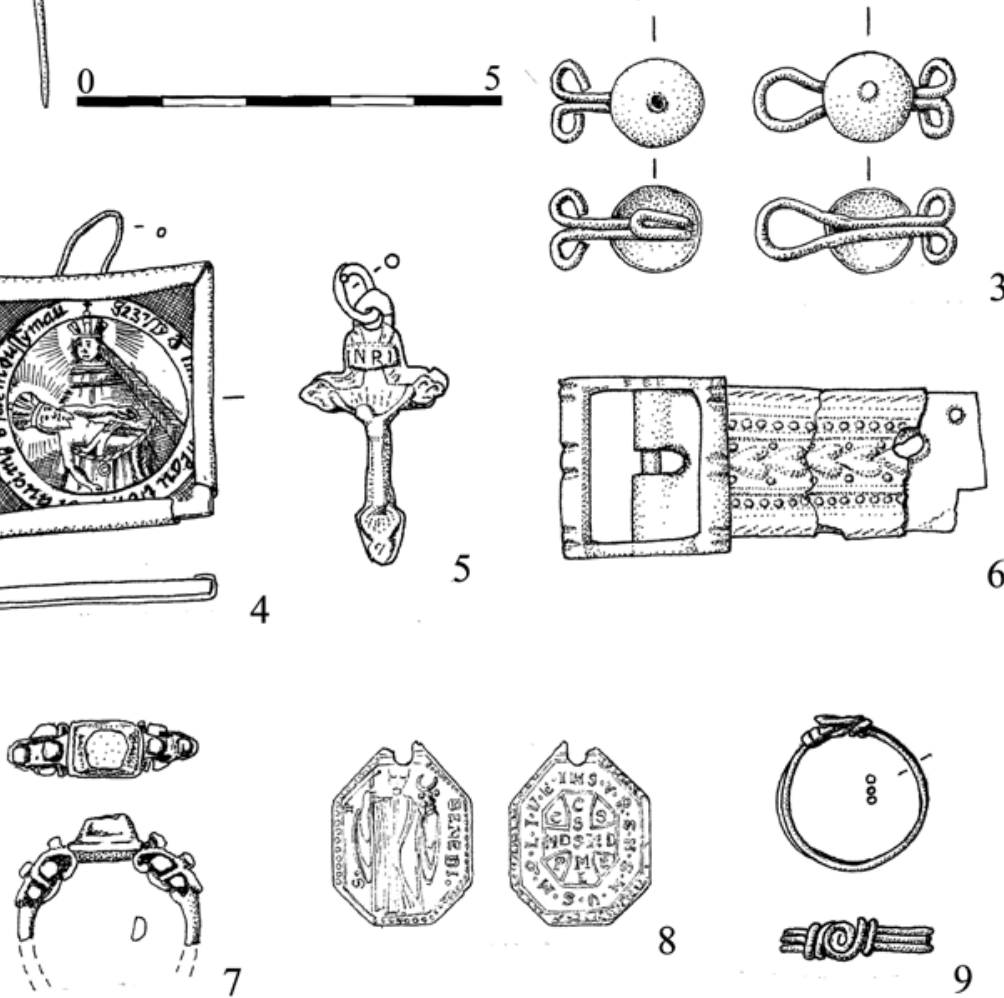

8

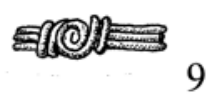

Obr. 5. Nesvady, poloha Jánoska part. Věasnonovoveké nálezy. Kresba Z. Nagyová.

Abb. 5. Nesvady, Lage Jánoska part. Frühneuzeitliche Funde. Zeichnung Z. Nagyová. 
drôtené ozdobné party (čelenky) s našitými korálikmi a plieškami (Kiss-Kiss 1994; Mérei 2010, 71-73; Selmeczi 2006; Lippok 2009). Žial', našli sa zväčša vo vel'mi torzovitom stave, často úplne spráchnivené. Súčastou odevu boli aj rôzne opasky zdobené kovaniami a ukončené prackou. V hrobe 76 sa odkryla dvojdielna bronzová pracka s upevňovacím plechovým kovaním, ktoré v stredovom páse zdobili reliéfnym, opakujúcim sa motívom srdca (obr. 5:6). Analogické predmety sú v Karpatskej kotline pomerne frekventované, napríklad Gortva-Bizovo (Drenko 1994, 147) a Gyula (Gábor 2006, 119-120). Plechové garnitúry opaskov z hrobu 155 sa síce v dôsledku oxidácie rozpadli, ale vd’aka zachovanému nákresu B. Szőkeho ich možno typologicky začlenit' medzi charakteristické nálezy 14.-16. storočia (Gábor 2006, 117-125).

Prstene sa vyskytli iba v troch včasnonovovekých hroboch. Pečatný prsteň s písmenom K na štíte bol oblúbeným šperkom v dobe vlády Anjouovcov (Hlatky 1938, 59). Našiel sa však v hrobe 25 v sprievode ihlíc a medailónu s nápismi Ježiš a Mária, ktoré však už patria do 17., resp. 18. storočia (Szentgáli 1942, 35[271]-38[274]). Neúplný strieborný prsteň so vsadeným očkom na prelamovanom štíte (obr. 5:7) sa dostal do nášho prostredia z Nemecka v priebehu 16. storočia (Hlatky 1938, 76-77). Medzi frekventované šperky sledovaného obdobia patrí aj prsteň so stočeným očkom z hrobu 176, ktorý zhotovili z tenkého bronzového drôtu (obr. 5:9). Evidujeme ho na viacerých lokalitách z územia Karpatskej kotliny.

Včasnonovoveké mince sa vyskytli iba v dvoch hroboch. Súbor prevažne strieborných razieb z hrobu 142, uložených pôvodne v koženom vrecúšku, nesúvisel s pohrebným rítom, ale predstavoval majetok pochovaného. V hrobe 77 , sa v l'avej ruke mŕtveho našla neskorá uhorská razba král’a Leopolda I. zo začiatku 18. storočia, v pravej ruke nebohého zas ležal kovový krížik.

Do kategórie sakrálnych predmetov úzko súvisiacich s pohrebným rítom patria medailóny (obr. 5:8) a krížiky, ktoré často tvorili súčast’ ružencov (obr. 5:5; 6:5-7; Szilágyi 1992). Medailóny sú zastúpené v hroboch z územia Karpatskej kotliny v mnohých variantoch (Hunka 2001). Napríklad medailón z hrobu 25 niesol nápis Ježiš a Mária. Jeden z medailónov v hrobe 77 pochádza $\mathrm{z}$ pútnického miesta $\mathrm{v}$ Mariacell, na druhom je zas reliéfne znázornený sv. Beňadik. Na náleze z hrobu 173 je vyobrazená Svätá rodina (obr. 6:7). Uvedené sakrálne razby medailí boli rozšírené najmä v druhej polovici 17. a v 18. storočí (Szentgáli 1942, 35[271]-38[274]. Neobvyklú svojráznu pamiatku označovanú termínom „breverl“ obsahoval hrob 151 (obr. 5:4). Ide o tlačené zobrazenie Panny Márie s mítvym Kristom v náručí - Piety, ktoré je uložené medzi sklíčkami s kovovým rámom (Kühtreiber-Fettinger-Heiss 2014, 124). Sledovaný sakrálny predmet je na základe nápisu spätý s Dómom svätého Mikuláša v Trnave a bol rozšírený v 17.-18. storočí. Jednoduchšie krížiky s korpusom boli súčastou inventára hrobov 14, 77 a 106. Ďalší krížik s kruhovými obrubami bez vsadených sklíčok sa našiel na cintoríne v sekundárnej polohe.

Kolekciu najbohatších a najhonosnejších predmetov včasnonovovekého cintorína obsahoval hrob 173, v ktorom pochovali ženu (obr. 6:1-7). Ležala pod hrobom 167 v híbke $190 \mathrm{~cm}$, dížka jej kostry bola $168 \mathrm{~cm}$. Významné spoločenské postavenie sledovanej osoby okrem hrobovej výbavy dokladá aj jej pohreb v rakve. Predlaktia mŕtvej boli umiestnené na bruchu, prekrížené nad sebou a v ruke držali ruženec. Očká ležali nielen pri článkoch prstov, ale siahali až po hornú čast' pravej stehennej kosti. Na vnútornej strane pravého stehna sa našiel medailón (obr. 6:7), pri lebke a v jej blízkosti viaceré ihlice (obr. 6:1-4), ktoré zdobili hlavu a odev pochovanej (Mérei 2010, 55-65). Béla Szőke zaznamenal na hrudi nebohej zvyšky textilu, ktorý zdokumentoval v nákrese plánu hrobu. Zrejme pochádzali zo šnúrami zdobenej vesty, ktorá bola v 16.-17. storočí bežnou súčastou ženského kroja (E. Nagy 1982, 64-65; Mojzsis 1985; Mérei 3010, 74-76). Pri pätách pochovanej sa našlo po jednom železnom okutí čižmy.

V hrobe 173 B. Szőke objavil viaceré ihlice rôznej vel'kosti s bohato profilovanou gul'ovitou hlavičkou a so vsadenými farebnými sklíčkami. Krátka ihlica s drobnou gulovitou hlavičkou (obr. 6:2) krášlila zrejme aj odev (Mérei 2010, 55-56). Mimoriadne zaujímavým predmetom v hrobe bola kolekcia súčastí v ruke držaného ruženca, ktorej visiaci koniec ukončili krížikom poskladaným z viacerých vyrezávaných kostených súčastí a medailónom (obr. 6:5-7). Z parohu vyrezané gul'ovité zrniečka - pôvodne 65 kusov - majú analógie v hroboch 5 a 41, nájdených v kostole Lech v Grázi (Lechner 1996, 136, tab. 28 a 147, tab. 39). Ruženec takmer totožný 

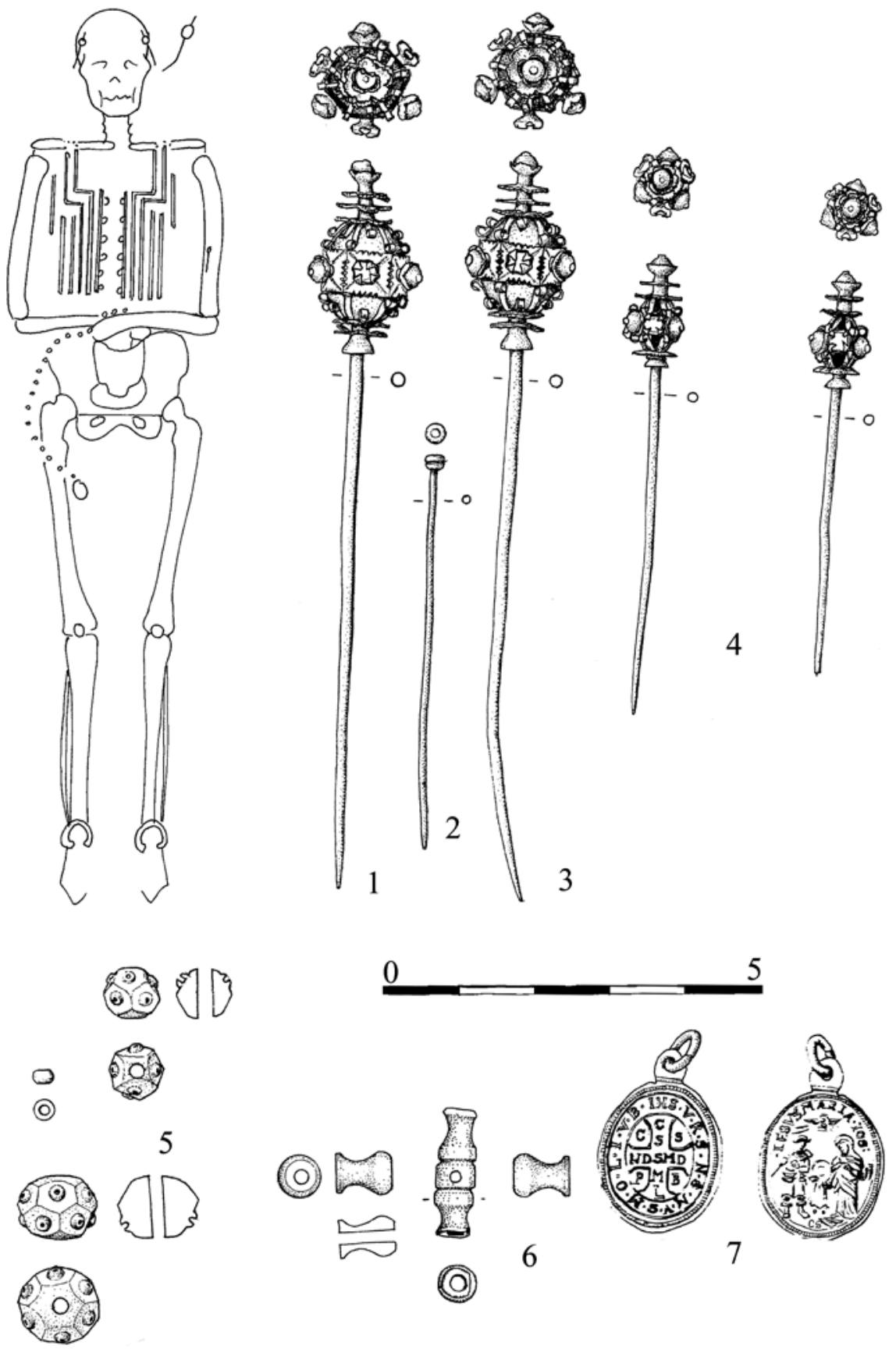

Obr. 6. Nesvady, poloha Jánoska part. Predmety z hrobu 173. Kresba Z. Nagyová. Abb. 6. Nesvady, Jánoska part. Grab 173 und seine Beigaben. Zeichnung $Z$. Nagyová. 
s nesvadským odkryli v probsteibergskom kláštore v Zwettli, v hrobe SE 334 (Kühtreiber-Fettinger-Heiss 2014, 173, tab. 17). Súčastou ruženca boli aj drobné sklenené očká v počte $43 \mathrm{ku}-$ sov. Na medailóne, ktorý sa nosil v druhej polovici 17. a v 18. storočí, je zobrazená Svätá rodina (Szentgáli 1942, 35[271]-38[274]).

Nálezy z hrobu 173, ale aj z iných ženských hrobov signalizujú, že aj napriek nestabilizovaným a nepokojným pomerom sledovaného obdobia existovala v Nesvadoch pomerne majetná vrstva obyvatel'stva, ktorá v obliekaní, ako aj v nosení šperkov kopírovala a úzko sledovala súdobú stredoeurópsku módu. Historické pramene, konkrétnejšie z rokov 1554, 1576, resp. 1669 dokumentujú časté spustošenia Nesvád (Borovszky 1907, 108-109). Napriek týmto negatívnym javom hroby analyzovaného cintorína svedčia o tom, že práve v 16. storočí obec so štatútom poddanského mestečka, nadobudla čoraz významnejšie postavenie.

Dôležitú rolu $\mathrm{v}$ tom zohralo jednak intenzívne obchodovanie a lacná preprava tovaru po rieke Nitra, ako aj susedstvo pevnosti v ned’alekých Nových Zámkoch.

Vd’aka obetavému prístupu Bélu Szőkeho sa nakoniec odborná dokumentácia a nálezy z Nesvád, predsa len zachovali a zachránili, i ked’ nie na jednom mieste. Ako výsledok intenzívneho výskumu archívnych a muzeálnych fondov sme nakoniec mohli realizovat' aj krátke predbežné vyhodnotenie tohto dôležitého a zabudnutého výskumu. Monografické spracovanie sledovanej lokality je pred ukončením.

Predložený príspevok vznikol vd’aka spoločného projektu SASPRO 0104/01/03, ktorý bol financovaný Slovenskou akadémiou vied a Európskou úniou.

\section{Literatúra}

BÁRDOS, E., 1987: Középkori templom és temető Kaposvár határában II. - Medieval Church and Cemetery in the Vicinity of Kaposvár II, Somogyi Múzeumok Közleményei 8, 5-82.

BÓNA, I., 1978: Árpádenzeitliche Kirche und Kirchhof im südlichen Stadtgebiet von Donaújváros, Alba Regia 16, 99-157.

BOROVSZKY, S., ed., 1907: Komárom vármegye és Komárom sz. kir. város. In: Magyarország vármegyéi és városai, 108-109. Budapest.

DOBOSI, J., 1997: Naszvad az én falum. Komárno.

- 2002: Naszvad. Nesvady.

DRENKO, Z., 1994: Zaniknutá stredoveká dedina Bizovo - Das abgegangene mittelalterliche Dorf Bizovo, ZbSNM LXXXVIII. Archeológia 4, 129-152.

FEHÉR, G.-ÉRY, K.-KRALOVÁNSZKY, A., 1962: A Közép-Duna-medence magyar honfoglalás- és kora Árpád-kori sírleletei. Leletkataszter. Budapest.

GÁBOR, G., 2006: Középkori pártaövek Békés megyében, A Békés Megyei Múzeumok Közleményei 28, $111-142$.

GÁLL, E., 2013: Az Erdélyi-medence, a Partium és a Bánság 10-11. századi temetői, szórvány- és kincsleletei. Budapest - Szeged.

GYÖRFFY, GY., 1987: Az Árpád-kori Magyarország történeti földrajza III. Budapest.

HAMPEL, J., 1907: Újabb tanulmányok a honfoglalási kor emlékeiről. Budapest.

HANULIAK, M., 1994: Malé Kosihy I. Pohrebisko z 10.-11. storočia. Nitra.

HEGEDÜS, A.-TÓTH, K., 2000: Egyházlátogatási jegyzőkönyvek katalógusa 9. Esztergomi főegyházmegye. Esztergom.

HLATKY, M., 1938: A magyar gyürü. Budapest.

HUNKA, J., 2002: Nálezy cirkevných sviatostiek zo 17. až 19. storočia zo Slovenska. In: Peníze v proměnách času 3, 235-242. Ostrava.

CHROPOVSKÝ, B., 1972: Príspevok k problematike cirkevnej architektúry a počiatkom krestanstva na Slovensku, Monumentorum tutela - Ochrana pamiatok 8, 173-208.

KISS, G.-KISS, E. CS., 1992: 17. századi női viseletmaradványok a szombathelyi Szent Márton templomban. Lapok Szombathely történetéből 14. Panniculus C/14. Szombathely. 
- 1992a: 17. századi férfi viseletmaradványok a szombathelyi Szent Márton templomban. Lapok Szombathely történetéböl 15. Panniculus C/15. Szombathely.

- 1994: 17-18. századi gyöngyös párták a szombathelyi Szent Márton templomból. Lapok Szombathely történetéböl 29. Panniculus C/36. Szombathely.

KOVÁCS, L., 1994: Das frühárpádenzeitliche Gräberfeld von Szabolcs. Varia Archaeologica Hungarica 6. Budapest.

KRAMMER, J., 1962: Szőke Béla, Arrabona 4, 5-8.

KRÁLIKOVÁ, M., 2007: Pohřební ritus 16.-18. století na území střední Evropy. Panoráma Antropologie 35. Brno.

KRUPICA, O., 1978: Krásno. Pohrebisko pri kostole, Západné Slovensko 5, 80-205.

KULCSÁR, M., 1996: Néhány megjegyzés az Árpád-kori karikaékszerek viseletének kérdéséhez. Az ún. köpüs záródású karikák, Savaria 22/3 (1992-1995), 249-275.

KÜHTREIBER, K.-FETTINGER, B.-HEISS, A. G., 2014: „... der Leichenfriedhof unter den Fenstern der Propsteiherrschafft ..." Der frühneuzeitliche Friedhof auf dem Probsteiberg in Zwettl, Beiträge zur Mittelalterarchäologie in Österreich 30, 111-176.

LEHNER, M., 1966: Die Archäologie des Leechhügels. In: Forschungen zur Lechkirche in Graz, Fundberichte aus Österreich, Materialhefte A/4, 19-156.

LIPPOK, J., 2009: Corona Funebris - Neuzeitliche Totenkronen. Beiträge zur Ur- und Frühgeschichte Mitteleuropas 54. Langenweissbach.

MADARAS, L., 2001: VII-VIII. századi avar temetőrészlet Berekfürdőből, Tisicum 12, 173-196.

MÉRAI, D., 2010: „The True and Exact Dresses and Fashion.“ Archaeological Clothing Remains and their Social Contexts in Sixteenth- and Seventeenth-Century Hungary. BAR International Series 2078. Oxford.

MOJZSIS, D., 1985: Magyar és spanyol típusú női öltözetek a nagylózsi leletben. (16-17. század), Mủvészettörténeti Értesítő 34, 150-154.

NAGY, K. E., 1982: Die Tracht eines vornehmen ungarischen Mädchens aus dem 16. Jahrhundert. Restaurierung und Rekonstruktion des Boldvaer Fundes, Ars Dekorativa 7, 29-79.

RUTTKAY, A., 1996: Mittelalterlicher Friedhof in Ducové, Flur Kostelec, Bez. Trnava. Beitrag zum Studium der Beziehungen zwischen den sog. Reihengräberfeldern und Kirchenfriedhofen vor dem 13. Jh. In: Ethnische und kulturelle Verhältnisse an der mittleren Donau vom 6. bis zum 11. Jahrhundert (Bialeková, D.-Zábojník, J., edd.), 391-408. Bratislava.

- 2005: Archeologický výskum kostola sv. Michala v Drážovciach a na jeho okolí. In: Dávne dejiny Nitry a okolia vo svetle najnovších archeologických nálezov (Ruttkay, M., ed.), 99-108. Nitra.

SELMECZI, L., 2006: „... Istentül adattál édes szűz koronám“. Adatok a párta történetéhez a Kárpát-medencében, Ethnographia 117, 17-64.

SZENTGÁLI, K., 1942: A kegyérmek ismeretének alapjai, Az Érem 10, 1(237)-14(250).

SZILÁGYI, I., 1992: Rózsafüzérek és tartozékaik a szombathelyi Szent Márton templomban. Lapok Szombathely történetéböl 17. Panniculus C/17. Szombathely.

SZÖKE, B., 1938: A városi múzeum újabb ásatásai Naszvadon, Érsekújvár és vidéke, szeptember, 18, 5.

- 1941: Honfoglalás kori sírok Naszvadon - Gräber der ungarischen Landnahmezeit in Naszvad, Folia Archaeologica 3-4, 214-224.

- 1955: Z minulosti musea v Novych Zámkách na Slovensku, AR VII, 528-529.

TOČÍK, A., 1983: Nedožitých 70 rokov Bélu Szőkeho - Szőke Béla meg nem élt 70. születésnapjára, Castrum Novum 2, 3-11.

\section{Zusammenfassung}

\section{Der mittelalterliche und frühneuzeitliche Kirchenfriedhof in Nesvady-Jánoska part} (Die Ausgrabungen Béla Szőkes in den Jahren 1938 und 1943)

Béla Szőke, Gründer und erster Direktor des Museums in Nové Zámky, betrieb auch in der Umgebung der Stadt seine Forschungen. In dem kaum $7 \mathrm{~km}$ südwestlich von Nové Zámky liegenden Dorf Nesvady erforschte Szöke neben landnahmezeitlichen Gräbern auch einen Teil eines Kirchenfriedhofs. Der Ausgrabungsort befand sich am östlichen Nitraufer, das nach einer darauf errichteten Statue des Heiligen Johannes von Nepomuk, Jánoskaufer genannt wurde (Abb. 1). Hier legte Szőke in den Jahren 1938 und 1943 ca. 300 mittelalterliche und frühneuzeitliche 
Gräber frei (Abb. 2). Neben zwei Zeitungsartikeln und einer kurzer Mitteilung stand nichts weiter über die Ausgrabung und die Funde zur Verfügung. Den Grund dafür konnten wir darin finden, dass der Ausgräber sowohl die Dokumentation als auch die Funde nach Győr mitnahm, wo sie im Museum am Anfang der 1960er Jahren inventarisiert wurden. Wegen des tschechoslowakisch-ungarischen Staatsvertrages gelangten die Funde nach Bratislava ins Nationalmuseum, die Dokumentation blieb aber im Museum zu Győr zurück. Die Grabungsdokumentation besteht aus den Notizen des Ausgräbers, Grabblättern, Grabzeichnungen und einem Plan des Friedhofes, worauf aber nicht alle Gräber eingezeichnet wurden.

Bei seinen Grabungskampagnen erforschte Béla Szöke einen Kirchenfriedhof, obwohl er die Ruinen der Kirche nicht beobachten konnte. Höchstwahrscheinlich wurden ihre Grundmauern ausgehoben. Nach den literarischen Angaben stand hier bis zum 18. Jahrhundert eine Kirche, die wahscheinlich noch im Laufe des 11. Jahrhundert gebaut wurde. Der Kirchenfriedhof war mehrschichtig, es wurde also ab dem 11. bis zum 18. Jahrhundert hier bestattet. Bei der Ausgrabung legte der Direktor eine Fläche von $350 \mathrm{~m}^{2}$ mit ca. 300 Gräbern frei. Aber nur für 275 stehen uns Grabblätter zur Vefügung.

Ungefähr die Hälfte der Gräber sind árpádenzeitlich, die durch die späteren Bestattungen stark gestört waren. Ihre Beigaben sind für die Epoche charakteristische s-förmige Schläfenringe aus Silber und Bronze (in mehreren Typen vertreten) sowie Perlen und Armringe mit Tierkopfenden. Einige Beigaben (Fingerringe usw.) deuten darauf hin, dass der Friedhof auch im 14. Jahrhundert benutzt wurde. Die Bestattungen des 16.-18. Jahrhunderts sind häufiger bzw. reicher in diesem Teil des Friedhofes. Die Verstorbenen lagen oft in Holzsärgen. Zahlreiche Variationen wurden bei der Lage der Arme bzw. Hände beobachtet. Grabkeramik fehlt vollständig. Die Beigaben der frühneuzeitlichen Gräber sind vielfältiger, wobei die Kleidungsbestandteile einen wesentlichen Teil ergeben. Neben zahlreichen Knöpfen und Schnallen kamen Schuh- bzw. Stiefelbeschläge aus Eisen zum Vorschein. Zur Frauentracht gehörten Haar- sowie Kleidungsnadeln, die hier in einigen Typen vertreten waren. Ebenfalls waren die Überreste von Totenkronen bzw. Gürtelbeschlägen vertreten. Kreuze und Wallfahrtsmedaillen befanden sich ebenso in den Gräbern. Besonders wichtig ist das Frauengrab 173 wegen seiner reichen Beigaben (Haarnadel, Rosenkranz mit Wallfahrtsmedaille usw).

Der vorliegende Beitrag entstand dank des von der Slowakischen Akademie der Wissenschaften und der Europäischen Union finanzierten Gemeinschaftprojektes SASPRO 0104/01/03.

PhDr. Gabriel Nevizánsky, CSc., Archeologický ústav SAV, Akademická 2, SK 94921 Nitra, Slovenská republika,nraunevi@savba.sk

Péter Prohászka, PhD., Archeologický ústav SAV, Akademická 2, SK 94921 Nitra, Slovenská republika, prohaszkapeter1975@gmail.com 
